Mr. Calvert Clapham states that "at Speeton it (the Red Chalk) is in some places a soft red clay, and is used to colour bricks and red pottery." Whenever the Red Chalk is found soft, like clay, at Speeton, it is because of its being displaced from its original bed and ground to a powder by large masses of white chalk which overlie the red chalk, falling upon it, and then the rains falling upon, or small streamlets passing through it, give it the consistency of "soft red clay;" but it is not to be found in a soft clayey state in situ. I must beg respectfully to state, that $\mathrm{Mr}$. C. Calvert is labouring under a mistake, when he states that the red chalk is used at Speeton for colouring either bricks or rough pottery : it is not so used; but an article very much the same in colour is used, viz. Venetian red, a sample of which $I$ enclose for your inspection, and remain,

Your obedient servant,

Edw. TiNDaLI.

\title{
Mammalian and Human Remains, Isle of Portland.
}

SIR,-Will you allow me to send you some remarks relating to an account, in the 'Times' of the 1st of January last, of some human and other bones which have been discovered associated together in fissures of the rock of Portland Island, during the building of the fortifications there?

The following is the passage in the "Times:- "The sections of the wonderful geological strata which form the Island of Portland are seen for the first time, in the straight rocky walls of the ditch, in all their curious variety. What is most singular is, that at regular intervals of twenty-five or thirty yards, and commencing about twenty feet below the surface of the ground, are a series of vertical faulta or gaps, about two feet wide, which, as far as can be judged, penetrate to the lowest substrata of the island, and traverse it completely from north to south. In these extraordinary clefts, human bones hare been found, with those of wild boars and horns of reindeer, not fossilized, but with all their osseous structure as perfect as if they were not fifty years old."

In 'Willis's Current Notes' for August, 1852, there is a nearly similar account of human and other bones found in the fissures of the Portland rock. The account says :- "It appears that in the year 1844, some human bones were discovered on the ledges of a fissure in a quarry belonging to Mr. Weston, at different depths, from twenty-five to forty feet. These fissures run parallel with each other throughout the island, from northeast to south-west, at stated distances, varying from forty-five to sixty feet, and the quarrymen say that they always know when they are coming near to them from the form the upper layers of loose stone and rubble assume, losing their longitudinal stratification, and having all the appearance of having been dragged out of their position by a mighty rush of water from above into the fissure. These fissures do not extend to the surface-soil by five or ten feet, and run down to the blue clay, through the several strata of stone, etc., to the depth of from eighty to a hundred feet, having many ledges or shelves in them, and generally covered with stalactitic formations. On several of these ledges a number of bones of all kinds of animals were found, including those of the liuman species. These were preserved and shown by Captain Manning to the late Rev. Dr. Buckland, on his next visit to the Castle; but the doctor having doubts as to the place where they were found, accompanied Captain Manning to the fissure, where a lad was let down who brought up more of the bones in his presence. 
Professor Buckland stated as his opinion, that the mass of matter of which the Island of Portland is composed on drying cracked and so formed these fissures. But how is it these fissures did not extend up to the surface-soil, where the evaporation must have been greatest, and where there appears no trace of them? Several teeth and a tusk of an elephant have recently been discovered in the dirt-bed of the Portland quarries."

The truth of these facts mentioned in the 'Current Notes,' which, in all material circumstances, are similar to the facts mentioned in the 'Times,' has been confirmed to me by Captain Manning himself, who has several times shown me, at Portland Castle, human and other bones, and amongst them those of the elephant, which have been discovered in the fissures of the Portland rock. Captain Manning stated that these fissures did not extend to the surface of the rock.

The truth of these geological facts may be easily ascertained by any person visiting Portland Island.

If human and other bones have been found in fissures which have no communication with the surface of the earth and are covered with solid stone, must they not have entered the rock before its consolidation, and, consequently, when it formed part of the bed of the sea? And must not, therefore, the men and animals to whom the remains belonged have inhabited some other dry land, which proviably no longer exists? And does not this render probable the opinion of M. Cuvier, expressed in the following words :- " I conclude, with MM. De Lac and Dolomieu, that if there be any fact well established in geology it is this, that the surface of our globe has suffered a great and sudden revolution, the period of which cannot be dated further back than five or six thousand years. This revolution has, on one hand, engulfed and caused to disappear the countries formerly inhabited by men and the animal species at present best known; and, on the other, has laid bare the bed of the last ocean, thus converting its channel into the present habitable earth "?

The period of this revolution, which MM. Cuvier, De Luc, and Dolomieu believe to have been effected by an interchange of land and sea, synchronizes very nearly with the one usually assigned to the Mosaic Deluge.

Your obedient servant,

Rectory, North Cerney, Cirencester, Jan. 23, 1863.

Thos. D. Aliman.

\section{Glyptolepis-Dura Den.}

Dear Sir,-The Rev. Mr. Mitchell, in his communication regarding this genus in your number for February, omits to mention that the discovery that what formerly used to be named Holoptychins Flemingi is in reality a species of Glyptolepis, is by no means quite new.

The attention of Professor Huxley, Mr. Robert Walker, of St. Andrew's, and myself, having been directed to the Dura Den fishes, in consequence of rather extensive excavations in the Den, which, through the kindness of Mrs. Dalgleish, were allowed to be made in the summer of 1861 , for furmishing specimens to the St. Andrew's Museum, we seem independently to have arrived at that conclusion. Towards the end of last summer, in writing me, of date 24th September, 1862, Mr. Walker states, "What was rather a curious coincidence," etc., "I left the Museum with a pretty strong conviction that the scales of Holoptychius Flemingi and Glyptolepis appeared to be one and the same, when here comes your letter 